J. Dairy Sci. 95:4591-4595

http://dx.doi.org/10.3168/jds.2012-5383

(C) American Dairy Science Association ${ }^{\circledR}, 2012$.

\title{
Short communication: Characteristics of proteolytic activities of endo- and exopeptidases in alfalfa herbage and their implications for proteolysis in silage
}

\author{
L. Tao, ${ }^{\star 1}$ X. S. Guo, $\dagger^{1}$ H. Zhou, ${ }^{\star 2}$ D. J. Undersander,‡ and A. Nandety \\ ${ }^{*}$ Institute of Grassland Science, College of Animal Science and Technology, China Agricultural University, Beijing 100193, PR China \\ †State Key Laboratory of Pastoral Agricultural Ecosystem, Institute of Arid Agroecology, School of Life Sciences, Lanzhou University, \\ 730000 China \\ ‡Department of Agronomy, University of Wisconsin, Madison 53706
}

\section{ABSTRACT}

The $\mathrm{pH}$ optimum and thermostability of both exopeptidases and endopeptidases were investigated in this study to elucidate the possible role of plant proteases in proteolysis during ensiling of alfalfa herbage. Proteolytic activities of 4 classes of endopeptidases (i.e., serine, metallo, aspartic, and cysteine peptidase) and 5 classes of exopeptidases (i.e., aminopeptidase, carboxypeptidase, dipeptidase, dipeptidyl-peptidase, and tripeptidyl-peptidase) were examined within $\mathrm{pH}$ values of 3 to 9 , and within temperatures from 20 to $90^{\circ} \mathrm{C}$. Serine and metalloproteases, the principal endopeptidases that hydrolyzed most of the protein to nonprotein nitrogen in alfalfa silage, had optimum activities at $\mathrm{pH}$ 4. Among the major exopeptidases contributing protein degradation in ensiled alfalfa, dipeptidase and tripeptidyl-peptidase had stable activities between $\mathrm{pH}$ 4 and 6 , and carboxypeptidase activity was optimal at $\mathrm{pH}$ 5. The optimum temperature for most peptidase activities was $40^{\circ} \mathrm{C}$. Proteolytic activities of both endo- and exopeptidases increased with the elevation of incubating temperature from 20 to $40^{\circ} \mathrm{C}$. The $\mathrm{pH}$ value in well-preserved alfalfa silage is often above 4.0, and the temperatures in the ensiled mass range from 25 to $40^{\circ} \mathrm{C}$. Therefore, high proteolytic activities between $\mathrm{pH}$ 4 and 6 and the temperature range of ensiled alfalfa suggest that plant peptidases play a role in hydrolyzing protein during prolonged storage.

Key words: exopeptidase, endopeptidase, alfalfa, proteolysis

\section{Short Communication}

Plant enzymes are usually thought to be responsible for most of the proteolysis of ensiled forage, with

\footnotetext{
Received January 25, 2012.

Accepted April 8, 2012.

${ }^{1}$ These authors contributed equally to this paper.

${ }^{2}$ Corresponding author: zhouhe@cau.edu.cn
}

subsequent degradation of AA attributed mainly to microbial activity (Heron et al., 1989). Kung and Bedrosian (2010) suggested that the contribution of plant proteases to nitrogenous changes during prolonged storage is doubtful because plant enzymes are quickly inactivated with a decrease in $\mathrm{pH}$. However, the extent of proteolysis in ensiled forage could be affected by the $\mathrm{pH}$ optimum of plant enzymes, rate and extent of $\mathrm{pH}$ decreases (McKersie, 1985), plant species (Papadopoulos and McKersie, 1983), DM content (Muck, 1987), and temperature (Muck and Dickerson, 1988). Optimal $\mathrm{pH}$ values for plant enzymes are often varied in different crops. The acid and alkaline endopeptidases in corn leaves were reported to have optimum activity at pH 5.4 and 7.5, respectively (Feller et al., 1977). The overall $\mathrm{pH}$ optimum for ryegrass proteases was 5.0 to 7.0 (Heron et al., 1989). McKersie (1981) reported that for alfalfa, the optimum $\mathrm{pH}$ values were 4.5 for acid proteinase, 6.7 for neutral proteinase, 5.4 for carboxypeptidase, and 6.5 for amino peptidase. These studies suggest that the optimum $\mathrm{pH}$ of alfalfa plant enzymes appears to be lower than other crops. Moreover, unlike corn or grass silages, the $\mathrm{pH}$ value in ensiled alfalfa forage is often above 4.0 (Owens et al., 1999; Schmidt et al., 2009), and even after 10 mo of storage, its $\mathrm{pH}$ value was reported to be between 4.3 and 4.6 (Kung et al., 2003).

Previous studies on the $\mathrm{pH}$ optimum of plant enzymes were investigated in terms of a general classification of proteolytic enzymes, such as acid, neutral, and alkaline proteases. Our studies showed that 4 classes of endopeptidases (i.e., serine, cysteine, aspartic, and metallopeptidases) and 5 classes of exopeptidase (i.e., aminopeptidase, carboxypeptidase, dipeptidase, dipeptidyl-, and tripeptidyl-peptidases) were present in alfalfa herbage, and each of them played a different role in alfalfa protein degradation and formation of different $\mathrm{N}$ constituents during fermentation of alfalfa green extract (Guo et al., 2011; Tao et al., 2011). However, to our knowledge, no study has been conducted 
to investigate the $\mathrm{pH}$ optimum and thermostability of these peptidases. Thus, our objective was to clarify the $\mathrm{pH}$ optimum and thermostability of both exopeptidases and endopeptidases in alfalfa herbage, and to elucidate the possible role of plant enzymes in proteolysis during ensiling of alfalfa.

Alfalfa (Medicago sativa L. 'Algonquin') was grown at experimental plots of the China Agricultural University $\left(116^{\circ} 18^{\prime} \mathrm{E}, 39^{\circ} 57^{\prime} \mathrm{N}\right)$ in Beijing, China. Fresh leaves were obtained from each of 4 experimental plots at the late budding stage, placed in small bags, and immediately frozen in liquid $\mathrm{N}$. The samples were then taken to the laboratory, where they were stored at $-80^{\circ} \mathrm{C}$ for later analysis.

Alfalfa leaves $(5 \mathrm{~g})$ from each field plot were ground in liquid nitrogen $(1: 4, \mathrm{wt} / \mathrm{vol})$ into powder in a mortar and pestle. The powder was then suspended in 20 $\mathrm{mL}$ of $25 \mathrm{mM}$ Tris- $\mathrm{HCl}$ (pH 7.5) containing 1\% (wt/ vol) insoluble polyvinylpolypyrrolidone and $0.1 \%$ (vol/ vol) $\beta$-mercaptoethanol. Samples were centrifuged (10 min at 20,000 $\times g$ ), and the supernatants were used directly for peptidase activity assays. For the analysis of peptidase activities, extracts were desalted at $4^{\circ} \mathrm{C}$ by application to Sephadex G-25 columns (Huarui Co., Beijing, China) equilibrated with $25 \mathrm{~m} M$ Tris- $\mathrm{HCl}$ [pH 7.5, containing $0.1 \%$ (vol/vol) $\beta$-mercaptoethanol; Feller et al., 1977].

A substrate solution of Pro-Thr-Glu-Phe-( $\left.\mathrm{NO}_{2}-\mathrm{Phe}\right)$ Arg-Leu for aspartic protease was prepared according to Cruz de Carvalho et al. (2001). Substrate of serine protease of N-succinyl-Ala-Ala-Pro-Phe $p$-nitroanilide was prepared as described by Wang et al. (2007). Substrate solution of cysteine proteases was prepared as described by Asano et al. (1999) with some modification. Briefly, 4-methylcoumaryl-7-amide (Z-Phe-Arg-MCA; same as Z-Phe-Arg-AMC) was dissolved in a minimal volume of dimethyl sulfoxide and then prepared in a $50 \mathrm{mM}$ sodium acetate buffer ( $\mathrm{pH} 4.0$ ), containing $200 \mathrm{mM}$ $\mathrm{NaCl}$ and $10 \mathrm{mM}$ 2-mercaptoethanol to a stock concentration of $40 \mu \mathrm{M}$. As a substrate of metalloproteinase, 2,4-dinitrophenyl (DNP)-Gly-Gly-Met-Arg was prepared according to Belozersky et al. (1990). Substrates for aminopeptidase, carboxypeptidase, dipeptidase, dipeptidyl-peptidase, and tripeptidyl-peptidase were prepared as previously described by Tao et al. (2011).

All enzyme activities were determined as described by Fischer et al. (1998) with some modification. Briefly, $1 \mathrm{~mL}$ of substrate solution was mixed with $0.25 \mathrm{~mL}$ of crude enzyme extracts of alfalfa leaves from each of the 4 field plots, and 4 replicates of the mixtures from each plot were incubated at $37^{\circ} \mathrm{C}$ for $30 \mathrm{~min}$ to determine the protease activity as a function of $\mathrm{pH}$; and when the protease activity as a function of temperature was determined, the mixtures were incubated at the designated temperature for $30 \mathrm{~min}$. Undigested substrates were precipitated by adding $2 \mathrm{~mL}$ of cold TCA $(5 \%$, wt/vol) and standing for $30 \mathrm{~min}$ before centrifugation $(5 \mathrm{~min}$ at $12,000 \times g)$. The liberated $\alpha$-amino groups in the supernatants were determined by the ninhydrin reaction (Friedman, 2004), and the concentration (mg/L) of the liberated AA was used to express enzyme activity. The assay performed without substrate served as the blank for each enzyme activity tested, and blank values subtracted from the tested values. The protease activity as a function of $\mathrm{pH}$ was determined using the specific substrate in buffers, which had adjusted $\mathrm{pH}$ values ranging from 3 to 9 in 1 -unit intervals. The buffer was adjusted to the designated $\mathrm{pH}$ by the addition of $\mathrm{HCl}$ or $\mathrm{NaOH}$ (McKersie, 1981). At the end of the incubation period, aliquots of incubated enzyme were assayed as described above. The optimum temperature of each protease was studied using a constant temperature bath at temperatures ranging from 20 to $90^{\circ} \mathrm{C}$ in $10^{\circ} \mathrm{C}$ intervals. Supernatant of alfalfa leaves, which contained mixed proteases, was combined with each specific substrate as described in the substrate solution preparation. At the end of the incubation period, aliquots of incubated enzyme were assayed as described above.

Data on enzyme activity responses to different temperatures and $\mathrm{pH}$ values were subjected to ANOVA using the one-way ANOVA procedure of SPSS software (SPSS 17.0 for windows; SPSS Inc., Chicago, IL), and separate ANOVA were completed for $\mathrm{pH}$ and temperature. Polynomial contrasts were used to test linear and quadratic effects of increasing $\mathrm{pH}$ and temperature, respectively. A probability of $P<0.05$ was used to denote significance unless otherwise indicated.

Responses of endo- and exopeptidases to $\mathrm{pH}$ values are shown in Table 1. Activities of serine, aspartic, and cysteine peptidase had linear and quadric $(P<0.001)$ responses to increasing $\mathrm{pH}$. Metallopeptidase activity had a linear decrease with increasing $\mathrm{pH}$ value $(P<$ 0.001 ). Serine and metallopeptidase activities were optimal at $\mathrm{pH} 4$ over the $\mathrm{pH}$ range of 3 to 9 . Serine peptidase was inactive above $\mathrm{pH} 8$, whereas metallopeptidase was inactive above $\mathrm{pH}$ 7. Therefore, these 2 peptidases appear to be the acid proteinase as classified by McKersie (1981). In contrast, aspartic peptidase was optimal at $\mathrm{pH} 7$, and was almost inactive at $\mathrm{pH} 5$, which suggests that this peptidase is a neutral proteinase (McKersie, 1981). Cysteine peptidase was optimal at $\mathrm{pH} 6$ and exhibited high activity between $\mathrm{pH} 6$ and 8. The optimal pH values of serine and metallopeptidase activities indicate that these 2 classes of peptidases are probably the major endopeptidases in 
Table 1. Responses of proteolytic activities of endopeptidases and exopeptidases to different $\mathrm{pH}$ values

\begin{tabular}{|c|c|c|c|c|c|c|c|c|c|c|}
\hline Proteolytic activity $^{1}$ & \multicolumn{7}{|c|}{ Incubation $\mathrm{pH}$} & $\mathrm{SE}$ & \multicolumn{2}{|c|}{$P$-value } \\
\hline \multicolumn{11}{|l|}{ Endopeptidase } \\
\hline Metallopeptidase & 3.9 & 5.9 & 5.3 & 0.8 & 0.0 & 0.0 & 0.0 & 0.55 & $<0.001$ & $<0.623$ \\
\hline Aspartic peptidase & 0.0 & 0.0 & 0.1 & 4.5 & 4.9 & 1.9 & 0.4 & 0.45 & $<0.001$ & $<0.001$ \\
\hline Cysteine peptidase & 0.0 & 0.1 & 1.9 & 3.9 & 3.6 & 3.6 & 0.0 & 0.37 & $<0.001$ & $<0.001$ \\
\hline Dipeptidase & 4.9 & 5.5 & 5.8 & 5.5 & 5.4 & 6.5 & 6.7 & 0.12 & $<0.001$ & $<0.001$ \\
\hline Carboxypeptidase & 2.1 & 4.6 & 6.3 & 3.0 & 2.5 & 0.5 & 0.0 & 0.45 & $<0.001$ & $<0.001$ \\
\hline Aminopeptidase & 1.8 & 3.2 & 3.6 & 12.4 & 9.7 & 8.7 & 6.7 & 0.80 & $<0.001$ & $<0.001$ \\
\hline
\end{tabular}

${ }^{1}$ The proteolytic activity was express as liberated AA concentration $(\mathrm{mg} / \mathrm{L})$ in the mixtures of substrate solution and crude enzyme extract after incubation at $37^{\circ} \mathrm{C}$ for $30 \mathrm{~min}$.

proteolysis during ensiling and storage. However, the $\mathrm{pH}$ optimum of aspartic peptidase and its response to $\mathrm{pH}$ values suggest that its role in proteolysis during ensiling of alfalfa silage is not as important as serine and metallopeptidases, and its contribution to proteolysis during the prolonged storage of alfalfa silage is doubtful. Research on alfalfa silage ensiled at different DM contents (from 201 to $560 \mathrm{~g} / \mathrm{kg}$ of DM), and with or without addition of inoculants, showed that within the prolonged storage period of 35 to $300 \mathrm{~d}$, $\mathrm{pH}$ values of the ensiled forage ranged from 4.29 to 5.08 (Mader et al., 1985; Schmidt et al., 2009). Characteristics of $\mathrm{pH}$ optimum and responses of the 4 endopeptidases to different $\mathrm{pH}$ values indicated that, of the peptidases identified in this study, serine and metallopeptidases appear to be the most important endopeptidases in hydrolyzing protein during ensiling of alfalfa, which is in agreement with previous reports (Pichard et al., 2006; Guo et al., 2011).

Activities of all exopeptidases displayed linear and quadratic $(P<0.001)$ responses to increasing $\mathrm{pH}$ value (Table 1). The optimal $\mathrm{pH}$ values of carboxypeptidase and aminopeptidase activity were at $\mathrm{pH} 5$ and 6 , respectively. Similar results were reported by McKersie (1981) who found that these 2 enzymes displayed maximal activity at $\mathrm{pH} 5.4$ and 6.5, respectively. Previous studies showed that carboxypeptidase retained above $40 \%$ of its original activity in alfalfa silage after $21 \mathrm{~d}$ of ensiling (McKersie and Buchanan-Smith, 1982; Guo et al., 2007). Aminopeptidase activity decreased substantially when the $\mathrm{pH}$ decreased below 5 in the current study, similar to the aminopeptidase activity in the study of McKersie and Buchanan-Smith (1982) where aminopeptidase was inactive in alfalfa after $5 \mathrm{~d}$ of ensiling. Activities of dipeptidase and tripeptidyl-peptidase, however, were relatively constant between $\mathrm{pH} 4$ and
6 . The above result provides supporting evidence that, among the 5 classes of exopeptidases, dipeptidase, carboxypeptidase, and tripeptidyl-peptidase were the principal exopeptidases for hydrolyzing forage protein into NPN during ensiling (Tao et al., 2011). Moreover, all 5 classes of exopeptidases and the endopeptidases of serine and metallopeptidase were still active at $\mathrm{pH} 3$, which further emphasizes that even decreasing the $\mathrm{pH}$ value to below 4 does not necessarily prevent proteolysis caused mainly by alfalfa plant proteinases (Heron et al., 1989).

Except for aspartic peptidase, which had only a quadratic $(P<0.001)$ response, the rest of the endopeptidases had linear and quadratic $(P<0.001)$ responses to increasing temperature (Table 2). The optimum temperature for serine peptidase, metallopeptidase, and cysteine peptidase was $40^{\circ} \mathrm{C}$ in our study, whereas aspartic peptidase had its optimum temperature for activation at $60^{\circ} \mathrm{C}$. Even at $70^{\circ} \mathrm{C}$, this peptidase exhibited a relatively high activity, indicating thermal stability of the enzyme. Activities of all exopeptidases had linear and quadratic $(P<0.001)$ responses to increasing temperature (Table 2). In agreement with the result of McKersie (1981), the optimum temperature for carboxypeptidase and dipeptidase activity was $40^{\circ} \mathrm{C}$, but for aminopeptidase, its activity remained relatively constant from 30 to $50^{\circ} \mathrm{C}$. The optimal temperature for dipeptidyl-peptidase and tripeptidyl-peptidase was $50^{\circ} \mathrm{C}$. These results suggest that the optimum temperature for most peptidase activities in alfalfa herbage is $40^{\circ} \mathrm{C}$. In addition, proteolytic activities of both endoand exopeptidase increased when the temperature of incubation rose from 20 to $40^{\circ} \mathrm{C}$, which could explain the increased proteolysis reported to occur in ensiled alfalfa when the storage temperature increased from 15 to $35^{\circ} \mathrm{C}$ (Muck and Dickerson, 1988). Studies have re- 
Table 2. Responses of proteolytic activities of endopeptidases and exopeptidases to different temperatures

\begin{tabular}{|c|c|c|c|c|c|c|c|c|c|c|c|}
\hline Proteolytic activity $^{1}$ & \multicolumn{8}{|c|}{ Incubation temperature $\left({ }^{\circ} \mathrm{C}\right)$} & $\mathrm{SE}$ & \multicolumn{2}{|c|}{$P$-value } \\
\hline \multicolumn{12}{|l|}{ Endopeptidase } \\
\hline Metallopeptidase & 1.7 & 3.1 & 4.9 & 3.2 & 0.4 & 0.0 & 0.0 & 0.0 & 0.37 & $<0.001$ & $<0.001$ \\
\hline Aspartic peptidase & 0.2 & 0.8 & 6.0 & 11.6 & 13.5 & 6.5 & 0.0 & 0.0 & 1.07 & 0.319 & $<0.001$ \\
\hline Cysteine peptidase & 1.1 & 2.0 & 2.8 & 2.7 & 0.0 & 0.0 & 0.0 & 0.0 & 0.24 & $<0.001$ & $<0.001$ \\
\hline Tripeptidyl peptidase & 1.7 & 3.4 & 5.8 & 6.3 & 5.3 & 1.5 & 0.0 & 0.0 & 0.55 & $<0.001$ & $<0.001$ \\
\hline Dipeptidase & 9.2 & 18.4 & 19.3 & 17.9 & 6.8 & 2.7 & 0.0 & 0.0 & 1.84 & $<0.001$ & $<0.001$ \\
\hline Carboxypeptidase & 6.2 & 12.3 & 14.7 & 5.9 & 4.5 & 0.0 & 0.0 & 0.0 & 1.26 & $<0.001$ & $<0.001$ \\
\hline Aminopeptidase & 7.1 & 12.3 & 12.4 & 12.2 & 4.5 & 0.0 & 0.0 & 0.0 & 1.27 & $<0.001$ & $<0.001$ \\
\hline
\end{tabular}

${ }^{1}$ The proteolytic activity was express as liberated AA concentration $(\mathrm{mg} / \mathrm{L})$ in the mixtures of substrate solution and crude enzyme extract after incubation at the given temperatures $\left(20\right.$ to $\left.90^{\circ} \mathrm{C}\right)$ for $30 \mathrm{~min}$.

ported that the maximum temperature of alfalfa ensiled in large bales (Han et al., 2004), tower silos (Merchen and Satter, 1983), and bunker silos (Goeser et al., 2011) to be approximately $40^{\circ} \mathrm{C}$ after 2 to 3 wk of storage. Temperatures in well-preserved alfalfa silage appear to range between 25 and $40^{\circ} \mathrm{C}$ (Jaster and Moore, 1988) and coincide with most peptidase activity as reported in our present study.

In summary, endopeptidases and exopeptidases in the alfalfa herbage had different responses to $\mathrm{pH}$ and temperature. The optimum $\mathrm{pH}$ values for endopeptidase of serine, metallo, and cysteine peptidase and for exopeptidase of dipeptidase, carboxypeptidase, and tripeptidyl-peptidase appeared to further confirm that they are major contributors to nitrogenous changes during the ensiling of alfalfa herbage. In addition, high proteolytic activities between $\mathrm{pH} 3$ and 6 of these peptidases may suggest that they could play a role in hydrolyzing proteins during prolonged storage.

\section{ACKNOWLEDGMENTS}

Financial support from the National Natural Science Foundation of China (Beijing, China; 30800800) is gratefully acknowledged.

\section{REFERENCES}

Asano, M., S. Suzuki, M. Kawai, T. Miwa, and H. Shibai. 1999. Characterization of novel cysteine proteases from germinating cotyledons of soybean. J. Biochem. 126:296-301.

Belozersky, M. A., Y. E. Dunaevsky, and N. E. Voskoboynikova. 1990. Isolation and properties of a metalloproteinase from buckwheat (Fagopyrum esculentum) seeds. Biochem. J. 272:677-682.

Cruz de Carvalho, M. H., A. d'Arcy-Lameta, H. Roy-Macauley, M. Gareil, H. El Maarouf, A.-T. Pham-Thi, and Y. Zuily-Fodil. 2001. Aspartic protease in leaves of common bean (Phaseolus vulgaris L.) and cowpea (Vigna unguiculata L. Walp): Enzymatic activity, gene expression and relation of drought susceptibility. FEBS Lett. 492:242-246.
Feller, U. K., T. T. Soong, and R. H. Hageman. 1977. Leaf proteolytic activities and senescence during grain development of field grown corn. Plant Physiol. 59:290-294.

Fischer, A., R. Brouquisse, and P. Raymond. 1998. Influence of senescence and carbohydrate levels on the pattern of leaf peptidases in purple nutsedge (Cyperus rotundus). Physiol. Plant. 102:385-395.

Friedman, M. 2004. Applications of the ninhydrin reaction for analysis of amino acids, peptides, and proteins to agricultural and biomedical sciences. J. Agric. Food Chem. 52:385-406.

Goeser, J. P., C. Heuer, and C. M. Wacek-Driver. 2011. Descriptive statistics for surface and core temperatures measured with infrared imagine and a digital thermometer on commercial Midwestern US silage. J. Anim. Sci. 89(E-Suppl. 1):305. (Abstr.)

Guo, X. S., W. Cheng, F. Y. Yang, and H. Zhou. 2011. Contribution of endopeptidase to the formation of nonprotein nitrogen during the ensiling process of alfalfa. Anim. Feed Sci. Technol. 168:42-50.

Guo, X., H. Zhou, Z. Yu, and Y. Zhang. 2007. Changes in the distribution of $\mathrm{N}$ and plant enzymatic activity during ensilage of lucerne treated with different additives. Grass Forage Sci. 62:35-43.

Han, K. J., M. Collins, E. S. Vanzant, and C. T. Dougherty. 2004. Bale density and moisture effects on alfalfa round bale silage. Crop Sci. 44:914-919.

Heron, S. J. E., R. A. Edwards, and P. Phillips. 1989. Effect of pH on the activity of ryegrass Lolium multiflorum protease. J. Sci. Food Agric. 46:267-277.

Jaster, E. H., and K. J. Moore. 1988. Fermentation characteristics and feeding value of enzyme-treated alfalfa haylage. J. Dairy Sci. 71:705-711.

Kung, L., Jr., and M. D. Bedrosian. 2010. How well do we really understand silage fermentation? Pages 87-93 in Proceedings of the Cornell Nutrition Conference For Feed Manufacturers, Cornell Univ., Ithaca, NY.

Kung, L. Jr., C. C. Taylor, M. P. Lynch, and J. M. Neylon. 2003. The effect of treating alfalfa with Lactobacillus buchneri 40788 on silage fermentation, aerobic stability, and nutritive value for lactating dairy cows. J. Dairy Sci. 86:336-343.

Mader, T. L., R. A. Britton, V. E. Krause, and D. E. Pankaskie. 1985 Effect of additive on alfalfa silage fermentation characteristics and feedlot performance of steers. J. Dairy Sci. 68:1744-1747.

McKersie, B. D. 1981. Proteinases and peptidases of alfalfa herbage. Can. J. Plant Sci. 61:53-59.

McKersie, B. D. 1985. Effect of $\mathrm{pH}$ on proteolysis in ensiled legume forage. Agron. J. 77:81-86.

McKersie, B. D., and J. Buchanan-Smith. 1982. Changes in the levels of proteolytic enzymes in ensiled alfalfa forage. Can. J. Plant Sci 62:111-116.

Merchen, N. R., and L. D. Satter. 1983. Changes in nitrogenous compounds and sites of digestion of alfalfa harvested at different moisture contents. J. Dairy Sci. 66:789-801. 
Muck, R. E. 1987. Dry matter level effects on alfalfa silage quality. I. Nitrogen transformations. Trans. ASAE 30:7-14.

Muck, R. E., and J. T. Dickerson. 1988. Storage temperature effects on proteolysis in alfalfa silage. Trans. ASABE 31:1005-1009.

Owens, V. N., K. A. Albrecht, R. E. Muck, and S. H. Duke. 1999. Protein degradation and fermentation characteristics of red clover and alfalfa silage harvested with varying levels of total nonstructural carbohydrates. Crop Sci. 39:1873-1880.

Papadopoulos, Y. A., and B. D. McKersie. 1983. A comparison of protein degradation during wilting and ensiling of six forage species. Can. J. Plant Sci. 63:903-912.

Pichard, G. R., B. R. Tesser, C. Vives, C. Solari, A. Hott, and R. E. Larraín. 2006. Proteolysis and characterization of peptidases in forage plants. Agron. J. 98:1392-1399.
Schmidt, R. J., W. Hu, J. A. Mills, and L. Kung Jr.. 2009. The development of lactic acid bacterial and Lactobacillus buchneri and their effects on the fermentation of alfalfa silage. J. Dairy. Sci. 92:5005-5010

Tao, L., H. Zhou, X. S. Guo, R. J. Long, and Y. Zhu. 2011. Contribution of exopeptidase to the formation of nonprotein nitrogen during the ensiling process of alfalfa. J. Dairy Sci. 94:3928-3935.

Wang, B., W. Wu, and X. Liu. 2007. Purification and characterization of a neutral serine protease with nematicidal activity from Hirsutella rhossiliensis. Mycopathologia 163:169-176. 